\title{
INTERLEUKIN-6 (-597G/A) POLYMORPHISM IN EGYPTIAN HEPATITIS C- VIRUS INFECTED PATIENTS
}

\author{
Mohamed Y. Nasr' ${ }^{1}$, Ammar S. Ali Deeb ${ }^{1}$, Gamal Badra ${ }^{2}$ and Ibrahim H. El \\ Sayed 1 . \\ ${ }^{1}$ Molecular Biology department, Genetic Engineering and Biotechnology Research \\ Institute, Sadat City University. ${ }^{2}$ Internal Medicine Department, National Liver Institute, \\ Menoufiya University.
}

\begin{abstract}
Raised levels of the interleukin (IL-6) have been reported in patients with Hepatitis C Virus (HCV), but it remains debatable whether they are influencedby IL-6 promoter polymorphisms. Therefore, this current study sought to assess whether IL-6(-597G/A) promoter polymorphisms are associated with serum IL-6 levels in HCV patients. Total 102 patients and 103 healthy controls were involved. Sequence specific primers-PCR (SSP-PCR) were used for $-597 \mathrm{G} / \mathrm{A}$ identification . Levels of IL-6 in serum samples were determined by enzyme linked immunosorbent assay (ELISA). The most frequent genotypes were $-597 \mathrm{G} / \mathrm{G}$ in patients and -579G/A in the control group. A significant increase $(\mathrm{P}<0.001)$ in $-597 \mathrm{G} / \mathrm{G}$, in the $\mathrm{HCV}$ group against controls, however -597G/A genotype was significantly decreased $(\mathrm{P}<0.001)$ in patients. Detection and differentiation of levels of IL-6 were significantly higher $(p=0.028)$ in patients infected with HCV compared with normal group. In serum IL-6 level non significant increase was observed in -597 polymorphism. These results investigate the evaluation of chronic HCV infection with a particular IL-6 polymorphism -597G/A in Egyptian population and there is no effect of polymorphism in IL-6 level.
\end{abstract}

Keywords: HCV, Polymorphism, IL-6, -597G/A.

\section{INTODUCTION}

Hepatitis $\mathrm{C}$ virus (HCV) is a single stranded RNA virus belonging to the flaviviridae family which mostly impacts the liver, It is estimated about 185 million people are infected with HCV throughout the world (Mohd et al., 2013). Approximately $70 \%$ of people infected with HCV develop chronic infection and the remaining $30 \%$ are known to spontaneously clear the infection; but these rates vary by ethnicity, gender, and other factors (Thomas et al., 2009).

Cytokines are immunomodulatory glycoproteins, which regulate the immune response and modulate the activities of the immune cells. Cytokines influence the defense against hepatitis viruses and immune response against hepatitis infections (Wan et al., 2009; Lu et al., 2015). It is involved in the regulation of different cellular processes, including proliferation and differentiation and plays a functional essential role in acute phase response and in the control of the equation between pro-inflammatory and antiinflammatory pathways, which could affect the result of antiviral treatment. (Shihara et al., 2002; Chihara et al., 2011; Ueyama et al., 2011). The human IL6 gene encoding on chromosome $7 \mathrm{p} 21$, and contains five exons and four introns (Ray et al., 1990). Recently, several polymorphisms, at most single nucleotide polymorphisms (SNPs), with biological importance have been reported in the IL-6 gene. These polymorphisms affect the level of interleukin-6 production. Production of IL- 
6 is regulated at the transcriptional, posttranscriptional and translational levels. (Liu et al., 2012; Lippitz 2013). Different SNPs in the IL-6 gene has been described to include in its transcriptional regulation, the mostcommon SNPs are $-174 \mathrm{G} / \mathrm{C}$ (rs1800795), -597G/A (rs1800797), and 572G/C(rs1800796) (Rasmussen et al., 2013; Jiao et al., 2014). It is shown that a polymorphism in the promoter region, would influence on the level of IL6 expression (Fishman et al., 1998). Prior studies definite the association between 174G/C polymorphism and HCV infection (Nattermann et al., 2007; Cussigh et al.,

\section{MATERIALS AND METHODS}

A sample of 102 consecutive Egyptian individuals; 74 males and 28 females, mean age $45.42 \pm 10.01$ years; range 23-69, with confirmed chronic HCV. Patients were from Oncology Hospital, Shebein El-kom, Menoufia Governorate, Menoufia University, Egypt. Also, a 103 unrelated healthy blood donors; 60 males and 43 females, mean age $28.89 \pm 8.40$ years; range 19-54, served as normal controls. The medical history was estimated from all participates. This study was previously approved by the Ethical Committee of The Institute of Genetic Engineering and Biotechnology Research, Written informed consent was obtained from all patients. (ELISA):

A measurement of serum IL-6 by

Total concentrations of IL- 6 in serum samples were measured using a commercial ELISA kit (R\&D System, Inc., Minneapolis, MN), according to the manufacturer's instructions. The intensity of the developed color was measured by reading optical absorbance at $450 \mathrm{~nm}$ using a microplate reader (SunriseTM, Tecan Group Ltd. Ma“ nnedorf, Switzerland) Results were expressed as pictogram of
2011). On the other hands, $-572 \mathrm{C} / \mathrm{G}$ (rs1800796), and-596G/A (rs1800797), have been reported to be related to a range of diseases, including hepatitis (Belluco et al., 2003; Tan et al., 2005).

There have been only a few studies dealing with the relationship between 597G/A IL-6 promoter polymorphism and chronic HCV infection, and their results have been incompatible, therefore the aim of this study was to investigate whether an evaluation of chronic HCV infection with a particular IL-6 SNPs (-597G/A) in Egyptian population and the correlation of the polymorphism with the level of serum IL-6.

cytokine per milliliter plasma $(\mathrm{pg} / \mathrm{ml})$ (Talaat et al., 2015).

\section{DNA Extraction}

Blood samples were collected in EDTA sterile tubes. Genomic DNA was isolated from whole blood, according to the manufacturer's instructions (Qiagen Ltd., UK).

SNP typing:

A IL-6 polymorphism (-597G/A) was detected by using study the sequencespecific primer (PCR-SSP) method. The primer for IL-6 (-597 G/A) was designed by using the aid of NCBI Primer-Blast Tool (http://www.ncbi.nlm.nih.gov/ tools/primerblast) (Forward G: 5' AAGTAACTGCACGAAATTTGAGGG3', Forward A: 5'AAGTAACTGCACGAAATTTGAGGA-

3', Reverse: 5'-TGTGCAATGTGACGTC CTTTA-3'). The PCR mixtures composed of the DreamTaq Green Master Mix 2x (Fermentas, Thermo Fisher Scientific Inc.), 10 pmoles of each allele-specific primer, 10 pmoles of reverse primer, and $100 \mathrm{ng}$ of DNA. PCR conditions regarding of the polymorphism was performed as follows: $94 \rightarrow C$ for $2 \mathrm{~min}$ (1 cycle), followed by $96 \rightarrow C$ for $25 \mathrm{~s}, 70 \rightarrow C$ for $45 \mathrm{~s}$, and $72 \rightarrow C$ for $20 \mathrm{~s}$ ( 5 cycles); followed by $96 \rightarrow \mathrm{C}$ for $25 \mathrm{~s}, 65 \rightarrow \mathrm{C}$ for $50 \mathrm{~s}$, and $72 \rightarrow \mathrm{C}$ for $45 \mathrm{~s}$ 
(11cycles); and finally $96^{\circ} \mathrm{C}$ for $25 \mathrm{~s}, 55^{\circ} \mathrm{C}$ for $60 \mathrm{~s}$, and $72 \rightarrow \mathrm{C}$ for $2 \mathrm{~min}$ (15 cycles). The size of the PCR product (473 bp) was analyzed by electrophoresis in $2 \%$ agarose gel after staining with ethidium bromide and evaluated in comparison to $100 \mathrm{bp}$ DNA ladder (Fermentas, Thermo Fisher Scientific Inc.). All PCR reactions were produced in the Biometra thermal cycler (Biometra GmbH, Germany).

Statistical analysis:

Data were fed into the computer and analyzed using IBM SPSS software package version 20.0. Qualitative data were described using numbers and percent. Quantitative data were described using range (minimum and maximum), mean, standard deviation and median. A significance of the obtained results was judged at the 5\% level.Comparisons between both groups were performed by Chi-square test For categorical variables to compare between different groups, Student t-test For normally quantitative variables to compare between two studied groups, Mann Whitney test For abnormally quantitative variables to compare between two studied groups.

\section{RESULTS}

Patients' characteristics:

Table (1) demonstrates the number, age, gender and Level of IL-6 from all investigate groups.

Table (1): Comparison between the two studied groups according to Age, Gender, and level of IL-6.

\begin{tabular}{llll}
\hline & Patients $(\mathrm{n}=102)$ & Control $(\mathrm{n}=103)$ & $\mathrm{p}$ \\
\hline Gender & & & \\
Female & $28(27.5 \%)$ & $48(46.6 \%)$ & $0.005^{*}$ \\
Male & $74(72.5 \%)$ & $55(53.4 \%)$ & $<0.001^{*}$ \\
Age & $45.42 \pm 10.01$ & $28.89 \pm 8.40$ & $<0.00 .028^{*}$ \\
IL-6 & $29.0(4.0-1086.0)$ & $29.30 \quad(3.70$ & $-0.0)$ \\
\hline
\end{tabular}

Qualitative data were described using number and percent and was compared using Chi square test, while normally quantitative data was expressed in mean $\pm \mathrm{SD}$ and was compared using student t-test, abnormally distributed data was expressed in median (Min. - Max.) and was compared using Mann Whitney test. *: Statistically significant at $\mathrm{p} \leq 0.05$

-597 G/A IL-6 polymorphism:

IL-6 SNP of (-597 G/A) allele and genotype frequencies in $\mathrm{HCV}$ patients and healthy control is shown in Table (2). The frequencies of GG, GA and AA genotypes in $I L-6-597 \mathrm{G} / \mathrm{A}$ were $59(57.8 \%), 42$ $(41.2 \%)$ and $1(1.0 \%)$ cases in $\mathrm{HCV}$ patients, respectively; and were $32(31.1 \%)$, $70(68.0 \%)$ and $1(1.0 \%)$ cases in controls, respectively. Analysis of IL-6 (-597G/A) SNP pointed to a significant increase
$(\mathrm{P}<0.001)$ in $\mathrm{GG}$ genotypes in the $\mathrm{HCV}$ group versus a significant decrease $(\mathrm{P}<0.001)$ in the same genotype in the control group. -597GA genotype increased significantly $(\mathrm{P}<0.001)$ in the control group. -597 AA genotype was rare in both controls and $\mathrm{HCV}$ cases (1.0\% for both). A significant increase $(\mathrm{p}<0.001)$ in the A allele was observed in the control group compared to $\mathrm{HCV}$. 
Table (2): Genotype distribution and allelic frequency of IL-6 (-597 G/A) in controls and HCV patients.

\begin{tabular}{llll}
\hline Cytokine gene & $\begin{array}{l}\text { Patients } \\
(\mathrm{n}=102)\end{array}$ & Control $(\mathrm{n}=103)$ & $\mathrm{P}$ \\
\hline IL 6 -597 & & & \\
G/G & $59(57.8 \%)$ & $32(31.1 \%)$ & $<0.001$ \\
G/A & $42(41.2 \%)$ & $70(68.0 \%)$ & $*$ \\
A/A & $1(1.0 \%)$ & $1(1.0 \%)$ & \\
Allele & & & \\
G & $160(78.4 \%)$ & $134(65.0 \%)$ & $0.003^{*}$ \\
A & $44(21.6 \%)$ & $72(35.0 \%)$ & \\
\hline
\end{tabular}

Qualitative data were described using number and percent and was compared using Chi square test, while normally quantitative data was expressed in mean \pm SD and was compared using student t-test, abnormally distributed data was expressed in median (Min. - Max.) and was compared using Mann Whitney test. *: Statistically significant at $\mathrm{p} \leq 0.05$

Serum levels of IL-6 in infected HCV patients:

A statistically significant increase of IL-6 ( $\mathrm{p} \leq 0.05)$ in infected HCV patients compared to healthy controls, $29.0 \pm(4.0-$ $1086.0)$ versus $29.30 \pm(3.70-139.0)$ was demonstrated. The disease was significantly correlated with elevation of IL-6 secretion level, Table (1).

Table (3): Relation between IL-6 level according to IL-6 (-597 G/A) in controls and HCV patients
The correlation between Serum Level of IL-6 and IL-6 (-597 G/A) polymorphism in controls and $\mathrm{HCV}$ patients:

Table (3) demonstrated the correlation between serum Level of IL-6 and IL-6 (-597 G/A) polymorphism, In IL6 (-597G/A), GG genotype, $\mathrm{G}$ and A alleles were non significant despite the increased serum IL-6 levels in patients.

\begin{tabular}{|c|c|c|c|c|c|c|c|c|}
\hline & & Median & $\begin{array}{l}\text { Patients } \\
\text { Min. - Max }\end{array}$ & $\begin{array}{l}\text { IL-6 l } \\
P\end{array}$ & $\begin{array}{l}\text { level } \\
\mathrm{N}\end{array}$ & Median & $\begin{array}{c}\text { Control } \\
\text { Min. - } \\
\text { Max }\end{array}$ & $\mathrm{p}$ \\
\hline \multicolumn{9}{|c|}{ IL 6 -597 } \\
\hline $\mathrm{G} / \mathrm{G}$ & 59 & 29.0 & $\begin{array}{c}4.0- \\
1086.0\end{array}$ & & 32 & 26.80 & $\begin{array}{l}5.20- \\
134.0\end{array}$ & \multirow[b]{2}{*}{0.773} \\
\hline G/A & 42 & 31.0 & $5.0-987.0$ & 0.860 & 70 & 30.95 & $\begin{array}{l}3.70- \\
139.0\end{array}$ & \\
\hline $\begin{array}{c}\text { A/A } \\
\text { Allele }\end{array}$ & $1^{\#}$ & \multicolumn{2}{|c|}{10.0} & & $1^{\#}$ & \multicolumn{2}{|c|}{25.70} & \\
\hline $\mathrm{G}$ & 160 & 29.0 & $\begin{array}{c}4.0- \\
1086.0\end{array}$ & 0.635 & 134 & 28.6 & $3.7-139.0$ & 0.887 \\
\hline A & 44 & 29.5 & $5.0-987.0$ & & 72 & 30.5 & $3.7-139.0$ & \\
\hline
\end{tabular}

Abnormally distributed data was expressed in median (Min. - Max.) and was compared using Mann Whitney test. $\mathrm{N}=$ number of samples.

*: Statistically significant at $\mathrm{p} \leq 0.05$ 


\section{DISCUSSION}

Studies on the cytokine gene polymorphisms (Barrett et, al. 2003; Tang et, al. 2014) suggest that inheritance of some genotypes related to polymorphisms of cytokine genes, such as the IL-6 gene, which become clear to affect cytokine production, may be host genetic factors associated with the progression of $\mathrm{HCV}$. With this overview, the present study was planned to identify the relationship between IL-6 (-597G/A) SNP, IL-6 serum levels and susceptibility to chronic HCV infection in Egyptian population.

Few studies examined the association between the IL-6 (-597G/A) SNP and HCV infection risk. In the present study, the distribution analysis of IL-6 (-597G/A) showed thatI L-6 -597 GG genotype had higher distribution in HCV patients $(57.8 \%)$ versus $(31.1 \%)$ in controls. While GA genotype had $(41.2 \%)$ distribution in HCV patients versus $(68.0 \%)$ in controls. On the other hand, there was a rarity in the IL-6597 AA Genotype in both groups (1.0\%).

Our result matches with Falleti et al., (2010) who observed the IL-6, -597 G/A polymorphism was related to the presence and outcome of HCV infection. Also, did

Cussigh et al., 2011 who reported the $(-597 \mathrm{G} / \mathrm{A})$ appear to favor a progressive $\mathrm{HCV}$ disease. In contrast to our study Lu et al. (2014) demonstrated, that no significant differences in the $(-597 \mathrm{G} / \mathrm{A})$ allele or genotype frequencies between the $\mathrm{HCV}$ patients and control group were observed.However, The different results of IL-6 promoter SNP (-597 G/A) of different studies have been inconsistent. Might be due to the great ethnic diversity in the world, further studies with subjects from different genetic background and different ethnic backgrounds would provide important information to understand the common between host and viral factors responsible for $\mathrm{HCV}$ pathogenesis and the clinical course of infection. (Fabrício et al., 2015; Tang et al., 2014).

This study demonstrated a significant increase in the IL-6 level in HCV patients compared to healthy people,the serum level of IL-6 in patients with HCV is controversial. Comanescu et al., (2015) and Fallahi et al., (2012)reported that IL-6 levels in patients with HCV were significantly higher than those in healthy controls.

Serum IL-6 levels related with viral load and histological index (Malaguarnera et al., 1997). Also the rapid serum clearance of IL-6 may give differing of results in the level of this inflammatory cytokine (Castell et al., 1989). On the other hand, lower levels of IL-6 associated with sustained virologic response, at most, in men (Ueyama et al., 2011). In the case of (597G/A) we observed high level of IL-6 GA genotype compared to GA and AA despite the fact that statistical significance, this finding agree with the report of Saxena et al. (2014) showed no significant difference in IL-6 levels in any of the genotypes of IL-6 -597G/A.

In conclusion, our results investigate the evaluation of chronic $\mathrm{HCV}$ infection with IL-6 polymorphism -597G/A in Egyptian population and the effect of polymorphism in IL-6 level, Further studies with large sample size are greatly needed to confirm the findings of this study. 


\section{REFERANCES}

Barrett, S., Collins, M., Kenny, C., Ryan, E., Keane, C.O. and Crowe, J. (2003). Polymorphisms in tumour necrosis factor-alpha, transforming growth factorbeta, interleukin-10, interleukin-6, interferongamma, and outcome of hepatitis $\mathrm{C}$ virus infection. J Med Virol, 71:212-218.

Belluco, C., Olivieri, F., Bonafe, M., Giovagnetti, S., Mammano, E., Scalerta, R., Ambrosi, A., Franceschi, C., Nitti, D. and Lise, M. (2003). $-174 \quad \mathrm{G}>\mathrm{C}$ polymorphism of interleukin 6 gene promoter affects interleukin 6 serum level in patients with colorectal cancer. Clin Cancer Res, 9(6):2173-2176.

Castell, J.V., Gómez-Lechón, M.J., David, M., Andus, T., Geiger, T., Trullenque, R., Fabra, R. and Heinrich, P.C. (1989). Interleukin-6 is the major regulator of acute phase protein synthesis in adult human hepatocytes. FEBS Lett, 242(2):237-239.

Chihara, N., Aranami, T., Sato, W., Miyazaki, Y., Miyake, S., Okamoto, T. and Yamamura, T. (2011). Interleukin 6 signaling promotes anti-aquaporin 4 autoantibody production from plasmablasts in neuromyelitis optica. Proc Natl Acad Sci U S A, 108(9): 3701-3706.

Comanescu, C., Bleotu, C., Huica, I., Radulescu, M., Grancea, C. and Anton, G. (2015). Non-invasive method for the evaluation of IL- 6 and IL-10 levels in patients with chronic hepatitis C.Rom Biotechnol Lett, 20(6):11018-11024.

Cussigh, A., Falleti, E., Fabris, C., Bitetto, D., Cmet, S., Fontanini, E., Bignulin, S., Fornasiere, E., Fumolo, E., Minisini, R., Pirisi, M. and Toniutto, P. (2011). Interleukin 6 promoter polymorphisms influence the outcome of chronic hepatitis C. Immunogenetics, 63(1): 33-41.

Fabrício-Silva, G.M., Poschetzky, B.S., de Mello Perez, R., Dos Santos, R.C., Cavalini, L.T. and Porto, L.C. (2015) Association of cytokine gene polymorphisms with hepatitis Cvirus infection in a population from Rio de Janeiro, Brazil. Hepat Med, 7: 71-79.

Fallahi, P., Ferri, C., Ferrari, S.M., Corrado, A., Sansonno, D. and Antonelli, A. (2012). Cytokines and HCV-related disorders. Clin Dev Immunol, 2012: 468107.

Falleti, E., Fabris, C., Vandelli, C., Colletta, C., Cussigh, A., Smirne, C., Fontanini, E., Cmet, S., Minisini, R., Bitetto, D., Toniutto, P. and Pirisi, M. (2010). Genetic polymorphisms of interleukin-6 modulate fibrosis progression in mild chronic hepatitis C. Hum Immunol, 71(10): 999-1004.

Fishman, D., Faulds, G., Jeffery, R., Mohamed-Ali, V., Yudkin, J.S., Humphries, S. and Woo, P. (1998). The effect of novel polymorphisms in the interleukin-6 (IL-6) gene on IL-6 transcription and plasma IL-6 levels, and an association with systemic-onset juvenile chronic arthritis. J Clin Invest, 102(7):13691376.

Jiao, F., Xu, D., Li, Q., Liu, G., Liu, H. and Ren, T. (2014). Lack of association between $-174 \mathrm{G}>\mathrm{C}$ and $-634 \mathrm{C}>\mathrm{G}$ polymorphisms in interleukin-6 promoter region and lung cancer risk: a metaanalysis. Tumor Biol, 35: 5021-5027.

Lippitz, B.E. (2013). Cytokine patterns in patients with cancer: a systematic review. Lancet Oncol, 14:e218e228.

Liu, S., Qiu, X.Q., Zeng, X.Y., Bai, H., Bei, C.H. and Yang, Y. (2012). Relationship between IL6 -572G/C polymorphism and hepatocellular carcinoma in men. Zhonghua Gan Zang Bing Za Zhi, 20(6):463-467.

Lu, Y., Bao, J.G., Deng, Y., Rong, C.Z., Liu, Y.Q., Huang, X.L. and Qin, X. (2015). Role of IL-18 Gene Promoter Polymorphisms, Serum IL-18 Levels, and Risk of Hepatitis B Virus-related Liver Disease in the Guangxi Zhuang Population: a Retrospective Case-Control Study. Asian Pac J Cancer Prev, 16(14): 6019-6026.

Lu Y, Wu Z, Peng Q, Ma L, Zhang X, Zhao J, Qin X, Li S (2014): Role of 
IL-4 gene polymorphisms in HBV-related hepatocellular carcinoma in a Chinese population. PLoS. One 2014;9: e110061.

Malaguarnera, M., Di Fazio, I., Laurino, A., Ferlito, L., Romano, M. and Trovato, B.A. (1997). Serum interleukin 6 concentrations in chronic heaptitis $\mathrm{C}$ patients before and after interferon-alpha treatment. Int $\mathrm{J}$ Clin Pharmacol Ther Toxicol, 35(9):385-388.

Mohd Hanafiah, K., Groeger, J., Flaxman, A.D. and Wiersma, S.T. (2013). Global epidemiology of hepatitis $\mathrm{C}$ virus infection: new estimates of age-specific antibody to $\mathrm{HCV}$ seroprevalence. Hepatology, 57(4):1333-1342.

Nattermann, J., Vogel, M., Berg, T., Danta, M., Axel, B., Mayr, C. and Kompetenznetz, H.A. (2007). Effect of the interleukin-6 $\mathrm{C} 174 \mathrm{G}$ gene polymorphism on treatment of acute and chronic hepatitis $\mathrm{C}$ in human immunodeficiency virus coinfected patients. Hepatology, 46(4): 1016-1025.

Rasmussen, L., Delabio, R., Horiguchi, L., Mizumoto, I., Terazaki, C.R., Mazzotti, D. and Payao, S.L. (2013). Association between interleukin 6 gene haplotype and Alzheimer's disease: a Brazilian case-control study. J Alzheimers Dis, 36(4): 733-738.

Ray, A., LaForge, K.S. and Sehgal, P.B. (1990). On the mechanism for efficient repression of the interleukin- 6 promoter by glucocorticoids: enhancer, TATA box, and RNA start site (Inr motif) occlusion. Mol Cell Biol, 10(11): 5736-5746.

Saxena, R., Chawla, Y.K., Verma, I. and Kaur, J. (2014). Association of interleukin-10 with hepatitis B virus (HBV) mediated disease progression in Indian population. Indian J Med Res, 139(5): 737745.

Shihara, K., and Hirano, T. (2002). IL-6 in autoimmune disease and chronic inflammatoryproliferative disease. Cytokine Growth Factor Rev, 13:357-368.

Talaat, R.M., Abdel-Aziz, A.M., ElMaadawy, E.A. and Abdel-Bary, N. (2015).CD38 and interleukin 6 gene polymorphism in egyptians with diffuse large B-cell lymphoma (DLBCL). Immunol Invest, 44(3):265-278.

Tan, D., Wu, X., Hou, M., Lee, S.O., Lou, W., Wang, J. and Gao, AC. (2005). Interleukin-6 polymorphism is associated with more aggressive prostate cancer. J Urol, 174(2):753-756.

Tang, S., Yuan, Y., He, Y., Pan, D., Zhang, Y., Liu, Y. and Liu, Z. (2014). Genetic polymorphism of interleukin-6 influences susceptibility to HBV-related hepatocellular carcinoma in a male Chinese Hanpopulation. Hum Immunol, 75(4): 297301.

Thomas, D.L., Thio, C.L., Martin, M.P., Qi, Y., Ge, D., O'Huigin, C. and Carrington, M. (2009). Genetic variation in IL28B and spontaneous clearance of hepatitis C virus. Nature, 461(7265): 798801.

Ueyama, M., Nakagawa, M., Sakamoto, N., Onozuka, I., Funaoka, Y., Watanabe, T., Nitta, S., Kiyohashi, K., Kitazume, A., Murakawa, M., Nishimura-Sakurai, Y., Sekine-Osajima, Y., Itsui, Y., Azuma, S., Kakinuma, S. and Watanabe, M. (2011). Serum interleukin-6 levels correlate with resistance to treatment of chronic hepatitis $\mathrm{C}$ infection with pegylated-interferon- $\alpha 2 b$ plus ribavirin. Antivir Ther, 16(7):10811091.

Wan, L., Kung, Y.J., Lin, Y.J., Liao, C.C., Sheu, J.J., Tsai, Y. and Tsai, F.J. (2009). Th1 and Th2 cytokines are elevated in HCV-infected SVR(-) patients treated with interferon-alpha. Biochem Biophys Res Commun, 379(4): 855-86 